\title{
Persistent organic pollutants in Finnish reindeer (Rangifer tarandus tarandus L.) and moose (Alces alces)
}

Anniina Suutari ${ }^{*}$, Anja Hallikainen ${ }^{2}$, Päivi Ruokojärvi ${ }^{3}$, Hannu Kiviranta $^{3}$, Mauri Nieminen ${ }^{4}$, Sauli Laaksonen ${ }^{5}$

From Environmental contaminants and animal health. The 26th Symposium of the Nordic Committee for Veterinary Scientific Cooperation (NKVet)

Helsinki, Finland. 6-7 October 2011

\section{Summary}

Background: The aim of this study was to determine 17 Polychlorinated Dibenzo-p-dioxin and Dibenzofuran (PCDD/F) and 12 Dioxin-like Polychlorinated Biphenyl (DL-PCB) concentrations in the tissues of Finnish terrestrial herbivore species, semi-domesticated reindeer (Rangifer tarandus tarandus L.), and wild moose (Alces alces), investigate transfer and accumulation of PCDD/Fs and DL-PCBs in milk of the lactating reindeer hinds, and explore contaminant concentrations in stillborn reindeer calves exposed via placental transfer to PCDD/Fs and DL-PCBs.

Methods: Reindeer and moose tissue sampling was focused in Finnish reindeer herding region. Reindeer milk samples were sampled in summer and autumn from reindeer hinds in experimental reindeer station in northern Finland. PCDD/Fs and DL-PCBs were analyzed using HRGC/HRMS method. The results are reported here as WHOTEQ upper bound concentrations and congener-specific lower bound concentrations.

Results: WHO-PCDD/F- and PCB-TEQs in reindeer muscle and liver were generally higher in the calves than in adults. Concentrations in moose calves were lower than in reindeer calves, while in adult reindeer and moose the levels were equal. General PCDD/F congeners in reindeer muscle and liver were 23478-PeCDF, 123678-HxCDD and OCDD. In reindeer milk, the highest PCDD/F detected was OCDD, and it was common also in the moose muscle samples. A strong contribution of non-ortho-PCBs to WHO-TEQ was detected in all studied samples. The most dominating non-ortho-DL-PCB congener was PCB-126 in reindeer muscle, liver and milk. In moose muscle samples PCB-77 was the most abundant congener. Species-, individual- and tissue-specific accumulation of PCDD/Fs and DL-PCBs may be the result from varying extent and quality of exposure, and to some extent from different metabolic potential.

Conclusions: PCDD/Fs showed partly similar profiles in reindeer and moose muscle, reindeer liver and milk samples - indicating equal mode of bioaccumulation. A strong contribution of non-ortho-PCBs to WHO-TEQ was detected, although there were some differences in frequency of particular congeners in these species. Due to the harmonized sampling method the study offers the way to determine and compare the levels of PCDD/Fs and DLPCBs in reindeer and moose tissues and examine the transfer and dynamics of dioxins and dioxin-like compounds in northern terrestrial food web.

\footnotetext{
* Correspondence: anniina.suutari@oulu.fi

'University of Oulu, Department of Biology, P.O. Box 3000, 90014 Oulu,

Finland

Full list of author information is available at the end of the article
} 


\section{Background}

Polychlorinated dibenzo- $p$-dioxins and dibenzofurans (PCDD/Fs) and dioxin-like polychlorinated biphenyls (DL-PCBs) are environmentally stable and toxic compounds, listed in Stockholm Convention [1] created to restrict and ultimately eliminate the production, use, release and storage of Persistent Organic Pollutants (POPs), and observed to exist globally in terrestrial and aquatic biota [2-4]. PCDD/Fs enter the environment solely as unintentional by-products from industrial and thermal processes, while DL-PCBs are merely intentionally produced chemicals that are released due to inappropriate disposal practices, accidents and leakages from industrial facilities $[2,5]$.

As lipophilic substances, PCDD/Fs and PCBs absorb passively from the gastrointestinal tract, enter the circulation and distribute to high lipid tissues such as white adipose. Metabolism and excretion of these compounds are slow leading to accumulation of these substances in the organism. Metabolism or biotransformation can also create reactive intermediates that may cause tissue damage as a consequence of binding to proteins (e.g. transthyretin), lipids and nucleic acids [2,6,7]. PCDD/Fs and DL-PCBs are able to cause an array of adverse health effects, like cancer, damage to the central and peripheral nervous systems, reproductive and developmental disorders, and disruption of the immune and endocrine systems [8-11].

Tissue specific contamination and toxicokinetics are related to the physiology of the animals [12]. Differences in lipid distribution and lipid class profile, as well as lipid dynamics like fat accumulation and fasting, may affect tissue concentrations of POPs [4,13]. Weight loss in winter due to sub-maintenance feed intake is normal for e.g. free-living reindeer. A new equilibrium and redistribution of POPs in the body is established due to fasting and lipid loss and depending of the species, different tissues of animals can be targets for possible toxic effects [1]. In addition, milk production and lactation rely on fat depots, are significant route of elimination, and may therefore alter the distribution and decrease body burden of POPs in females [14].

Species-specific exposure, metabolism and accumulation of POPs result in different concentrations and contaminant profiles in the studied species. Ecophysiological factors, like feeding, may have an impact on the congener pattern seen in the animal body. E.g. PCDD/F profile in roe deer liver resembles that in conifer shoots (indicator for deposition via air), while profile in sheep liver is more similar with that of soil, indicating different eating behaviors [15]. Accumulation patterns may also vary among individuals of the same species, for example, Finnish reindeer fed only on natural pastures had higher PCDD/Fand DL-PCB concentrations than reindeer who had got supplementary feed [16]. Finnish reindeer and moose are interesting study objects because they share common living and contaminant deposition areas, and both are used as foodstuffs. Species-specific differences and elimination of dioxins in these economically, culturally and environmentally important Cervid species are highly interesting.

Age is considered to be one of the factors affecting POP levels. Generally, older individuals have higher POP levels than younger ones $[17,18]$. However, studies on reindeer in Finland have revealed higher concentrations in reindeer calf muscle than in adult reindeer muscle [19]. Accumulation of POPs in the early life stages of reindeer is supported by the observation of PCDD/Fs and DL-PCBs in Finnish stillborn reindeer calves [20]. Contaminant transfer from hind to fetus via placenta is occurring at critical and sensitive time period (body fat mobilization in mother and sensitive periods of organogenesis in fetus) resulting increased stress. Thyroid and steroid hormone systems are among the sensitive endocrine variables involved in the regulation of metabolic processes and development, and are potential targets of POPs both in hind and in fetus [21].

In addition to TEQs that are needed for risk assessment, the studies on individual congener profiles of PCDD/Fs and DL-PCBs in animal tissues give more detailed information on sources of exposure, species differences, individual variation, and differences among life stages and tissues. TEQ concentration, which is a measure of the total amount of PCDD/Fs and DL-PCBs adjusted for toxic potency, is a simplified method of assessing the risk of dioxin/PCB mixtures [22]. TEQ refers to the sum of the amounts of PCDD/Fs and DL-PCBs multiplied by their relative toxic potency as related to TCDD (the most toxic congener) according to the WHO [23].

The purpose of this study was to determine the concentrations and accumulation of 17 toxic $\mathrm{PCDD} / \mathrm{F}$ congeners and 12 DL-PCB congeners in semi-domesticated reindeer and wild moose in order to identify the congener profiles of PCDD/Fs and DL-PCBs and reveal possible speciesand tissue-specificity in accumulation. Standardized sampling method allowed a spatial survey of contaminant levels and profiles.

\section{Methods}

The sampling area of reindeer and moose located in the sub-arctic northern Finland (Figure 1) and covered the reindeer herding region. The region was divided into three different sampling zones; the northern, the middle and the southern zone. The method of sampling was standardized hence allowing a comparison of the results between the different zones. The samples were built up in a ratio of carcass meat consumption. Concentrations of 17 toxic PCDD/F and 12 DL-PCB (dioxin-like PCBs; 4 


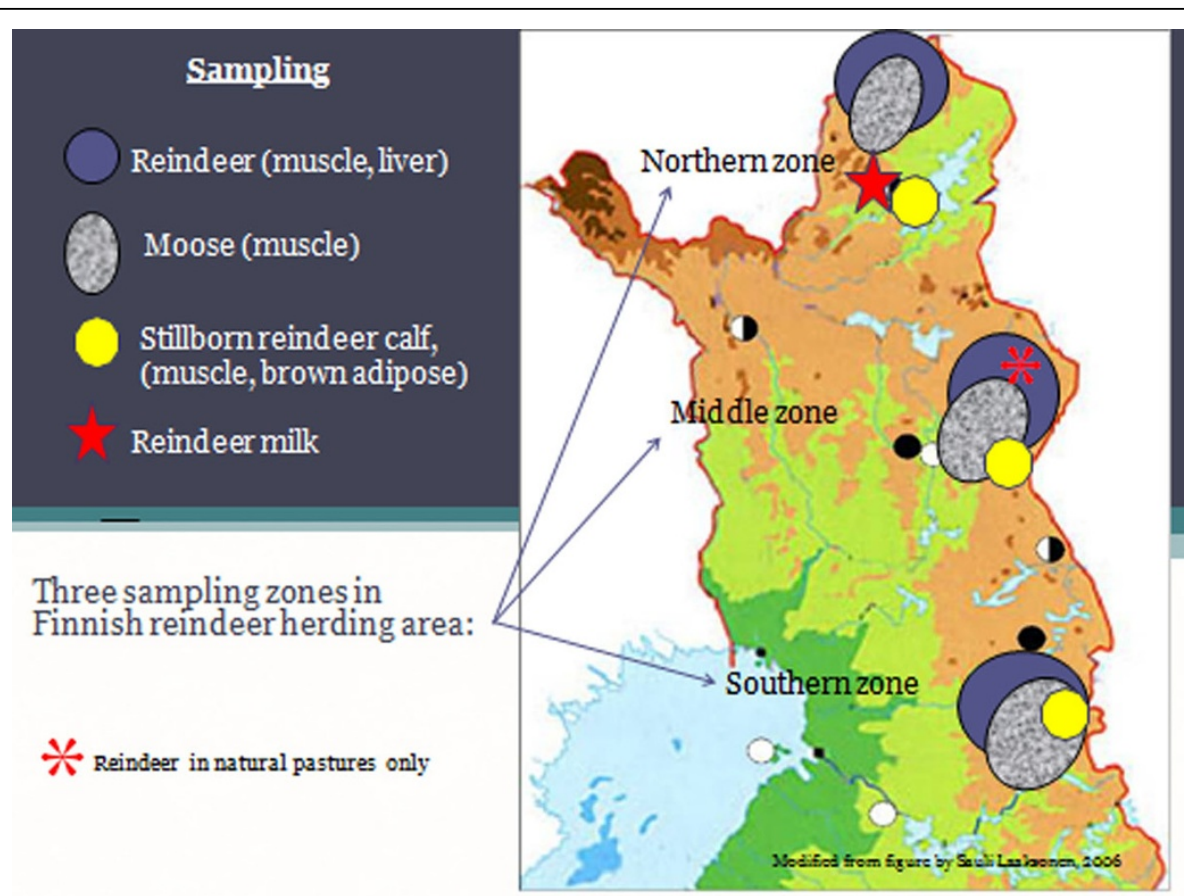

Figure 1 Sampling area.

non-ortho and 8 mono-ortho congeners) were measured from each sample (Table 1).

\section{Reindeer and moose muscle samples}

The pooled muscle samples (weight $500 \mathrm{~g}$ ) of reindeer $(\mathrm{n}=40)$ and moose $(\mathrm{n}=12)$ consisted of $200 \mathrm{~g}$ rump, $200 \mathrm{~g}$ rib and fore back, and $100 \mathrm{~g}$ shoulder muscle. The sampling was conducted using a clean knife and nitrile gloves to prevent contamination. The samples were stored in polyethylene bags in $-20^{\circ} \mathrm{C}$ until analysis.

\section{Stillborn reindeer calves}

The muscle samples (on average $270 \mathrm{~g}$ ) of stillborn reindeer calves $(n=11)$ were collected from spontaneously

Table 1 Analyzed PCDD/Fs and DL-PCBs with toxic equivalent factors

\begin{tabular}{|c|c|c|c|}
\hline Congener & TCDD equivalent & Congener & TCDD equivalen \\
\hline$\underline{P C D D / F S}$ & & Non-ortho-PCBS & \\
\hline 2378-TCDF & 0.1 & PCB-77 & 0.0001 \\
\hline 2378-TCDD & 1 & PCB-81 & 0.0001 \\
\hline 12378-PeCDF & 0.05 & PCB-126 & 0.1 \\
\hline 23478-PeCDF & 0.5 & PCB-169 & 0.01 \\
\hline 12378-PeCDD & 1 & Mono-ortho-PCBs & \\
\hline 123478-HxCDF & 0.1 & PCB-105 & 0.0001 \\
\hline 123678-HxCDF & 0.1 & PCB-114 & 0.0005 \\
\hline 234678-HxCDF & 0.1 & PCB-118 & 0.0001 \\
\hline 123789-HxCDF & 0.1 & PCB-123 & 0.0001 \\
\hline 123478-HxCDD & 0.1 & PCB-156 & 0.0005 \\
\hline 123678-HxCDD & 0.1 & PCB-157 & 0.0005 \\
\hline 123789-HxCDD & 0.1 & PCB-167 & 0.00001 \\
\hline 1234678-HpCDF & 0.01 & PCB-189 & 0.0001 \\
\hline 1234789-HpCDF & 0.01 & & \\
\hline 1234678-HpCDD & 0.01 & & \\
\hline OCDF & 0.0001 & & \\
\hline OCDD & 0.0001 & & \\
\hline
\end{tabular}


aborted calves. The samples consisted of rump, back and shoulder muscles. Brown adipose tissue (BAT) samples $(n=3)$ were taken from stillborn calves of the middle and southern sampling zones. BAT samples were collected from the specific locations; around the shoulders, sternum, trachea and spinal cord, and from the abdominal and thoracic cavities. The samples weighted on average $20 \mathrm{~g}$.

\section{Reindeer liver samples}

The reindeer livers $(\mathrm{n}=14)$ were taken as solid tissues from reindeer calves and adult reindeer by using a clean knife and nitrile gloves to prevent contamination. The samples were stored in polyethylene bags in $-20^{\circ} \mathrm{C}$ until analysis.

\section{Reindeer milk samples}

The reindeer milk samples were gathered in the Kaamanen experimental reindeer station in Inari, localizing in the northern sampling zone. Milk samples were collected twice from the reindeer hinds $(n=7)$, in the early summer and later in the autumn. The sample collection $(30 \mathrm{ml}$ in each) was performed by hand milking to pre-cleaned glass bottles. The milk collection was facilitated by using Oxytocin (10 IU, i.m.) to each hind. Milk samples were preserved frozen $\left(-20^{\circ} \mathrm{C}\right)$ in dark until analysis.

\section{Chemical analysis}

The analyses were performed at the accredited reference laboratory of chemistry at the National Institute for Health and Welfare in Finland. The requirements of standard EN ISO/IEC 17025 were completed. After homogenization the samples were freeze dried and fat was extracted with ethanol-toluene using Accelerated Solvent Extractor (ASE 300) equipment. The solvent was exchanged to hexane and the fat content was determined gravimetrically. The samples were defatted on an acidic silica column and purified and fractionated on alumina and carbon columns. PCDD/Fs and PCBs were analyzed with HRGC/HRMS using a selected ion monitoring mode (SIM) and resolution of 10000 . Further details of the analytical method can be found elsewhere [20].

\section{Reporting of the results}

WHO-TEQ concentrations are reported as fat based upper bound concentrations (concentrations $<\mathrm{LOQ}=$ $\mathrm{LOQ}$ ) to enable comparisons to the existing EU maximum level in the meat [24]. The most abundant congener-specific PCDD/F and DL-PCB concentrations are reported as lipid based lower bound concentrations (concentration $<\mathrm{LOQ}=0$ ). Blank samples covering the whole analytical procedure did not indicate any cross contamination.

\section{Statistical analysis}

Statistical analysis was conducted using the SPSS 16.0 software. Analysis of variance (ANOVA) was used to detect significant differences among data set, when data were normally distributed. Kruskal-Wallis test was used if homogeneity of variances did not realize. The criterion for significance was $p<0.05$.

\section{Results and discussion}

\section{$\mathrm{PCDD} / \mathrm{Fs}$ in reindeer and moose tissue samples}

WHO-PCDD/F-TEQs in reindeer muscle (Figure 2 a) were quite equal (on average $1.2 \mathrm{pg} / \mathrm{g}$ fat) in the different sampling zones, being only moderately higher in the southern zone, and generally higher in the calves than in adults. WHO-PCDD/F-TEQs in reindeer liver (Figure $2 \mathrm{~b}$ ) followed the same pattern than in muscle: higher levels in the calves and in the southern zone. The most prominent $\mathrm{PCDD} / \mathrm{F}$ congeners in reindeer muscle samples were 23478-PeCDF, 123678-HxCDD and OCDD (Figure 3 a), of which 23478-PeCDF and OCDD were also characteristic for reindeer liver samples. In addition, 123478-HxCDF, 123678-HxCDF, 234678-HxCDF and 1234678-HpCDD were well representative in liver (Figure $3 \mathrm{~b}$ ). For the comparison, some of these congeners found in reindeer liver, namely 23478-PeCDF, 1234678-HpCDD and OCDD, have been the most common congeners in roe deer liver samples in Germany [15]. Despite of the different zoogeographical origin of the species, roe deer's feeding behavior resembles that of reindeer: variety of grasses, lichens, mushrooms, twigs and branches.

In this study, OCDD, with relatively low toxicity (TEF 0.0001 ) had a special property to exist at high concentrations (up to $140 \mathrm{pg} / \mathrm{g}$ fat) in reindeer muscle and liver in the northern area calf samples. This may indicate special and different exposure to OCDD from some wide scale emission source in the northern Finland, considering that adult reindeer in the same area also had proportionate high OCDD concentrations, especially in their liver. Also 2005 sampled reindeer calves in North-East Finland have shown high (160-fold) OCDD concentrations in muscle compared to many other existing PCDD/F congeners. The more toxic PCDD/F congener, 23478-PeCDF (TEF $0.5)$ concentrations were high in the calves and adult reindeer of the southern area, especially in their livers. This congener showed also high contribution in stillborn calves' muscle tissue in the same area, and also in middle area's stillborn calf muscle. Statistically significant differences $(P<0.05)$ were seen in the concentrations of 2378TCDF, 123478-HxCDD and 1234678-HpCDF, which showed to exist in higher levels in the calf, especially in stillborn calf, muscle samples in every sampling zone. On the contrary, 12378-PeCDF concentrations were significantly $(P<0.05)$ higher in adult reindeer muscle samples. 


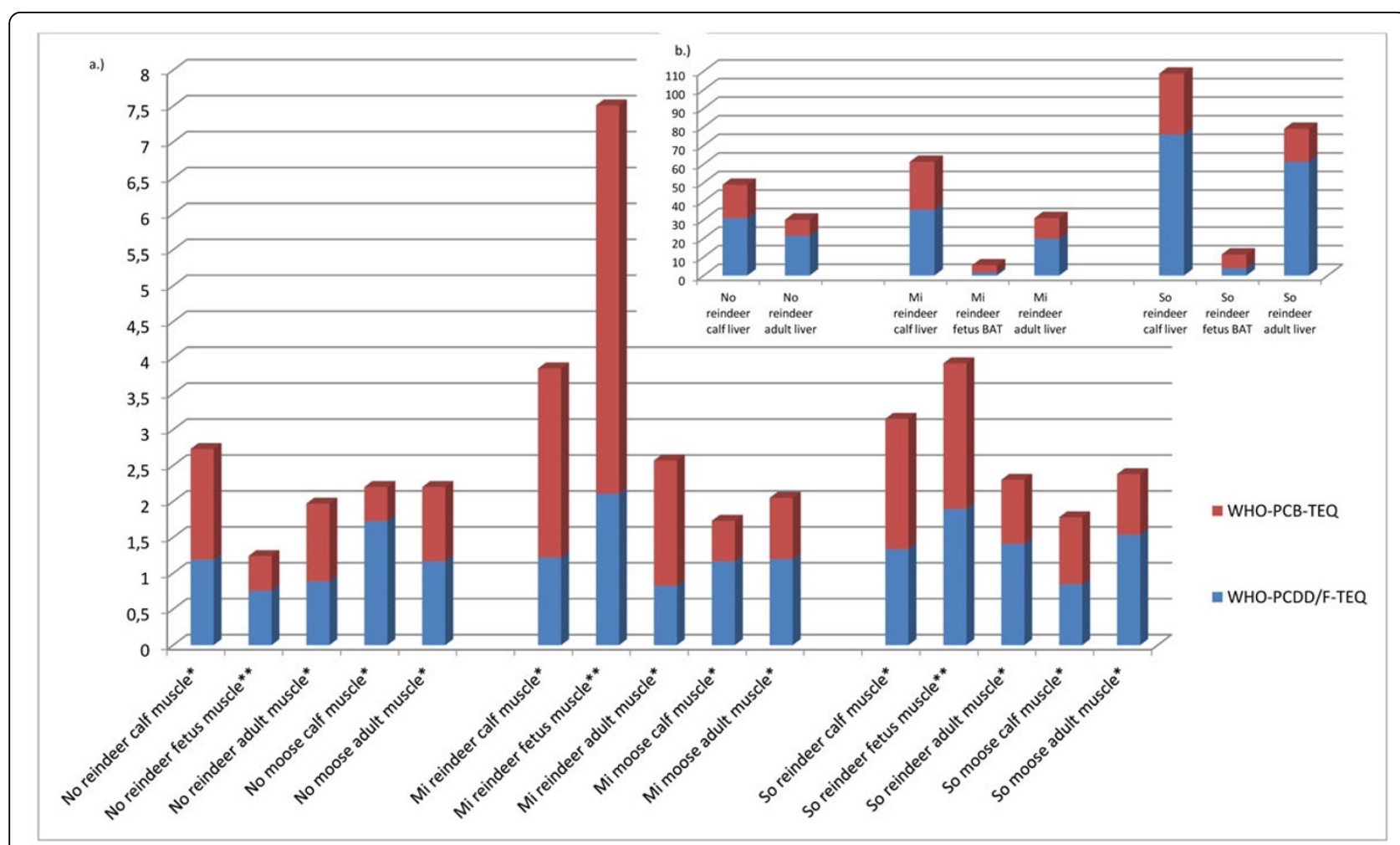

Figure 2. ${ }^{*}[16],{ }^{* *}[20]$. No=Northern zone, Mi=Middle zone, So=Southern zone. BAT=Brown adipose tissue.

Figure 2 WHO-PCDD/F- and WHO-PCB-TEQs (pg/g fat) in a.) reindeer and moose muscle samples, and b.) in reindeer liver and brown adipose samples. *[16], **[20]. No=Northern zone, Mi=Middle zone, So=Southern zone. BAT=Brown adipose tissue.

WHO-PCDD/F-TEQs in stillborn calves' muscle were slightly higher in the middle and southern zone (on average $2 \mathrm{pg} / \mathrm{g}$ fat) than in the northern zone $(0.8 \mathrm{pg} / \mathrm{g}$ fat $)$.

Considering stillborn calves' brown adipose tissue, it was seen that mean 23478-PeCDF concentration (2.4 pg/g fat) was overwhelmingly highest of any congeners (data not shown), and thus affected strongly (TEF $=0.5)$ to the WHO-PCDD/F-TEQs, which were 1.7 and $4.1 \mathrm{pg} / \mathrm{g}$ fat in the studied middle and southern areas (Figure $2 \mathrm{~b}$ ). However, also many other PCDD/F congeners existed in brown adipose and three of them (2378-TCDD, 123478HxCDD and 123678-HxCDD) were lacking in muscle samples but represented in the brown adipose. On the other hand, 2378-TCDF, 1234678-HpCDD and OCDD seemed to exist in the muscle samples, but not in brown adipose, of stillborn reindeer calves.

Highly chlorinated congeners like $1234678-\mathrm{HpCDD}$ and OCDD are generally considered to accumulate well in lipid-rich tissues, like brown adipose (fat content on average $30 \%$ ), so the lack of these congeners is interesting. It may be the strong binding of these high chlorinated congeners to reindeer hind's fat storages that restricts the transplacental diffusion to brown adipose of fetus. However, the muscle of fetus contained 1234678$\mathrm{HpCDD}$ and OCDD in the middle and southern zones that may be indication of individual variations. There are indications of tissue-specific retention of $\mathrm{PCDD} / \mathrm{Fs}$ in animals [25] that may be caused by structural specific binding sites and relative degree of absorption; those may partly explain different profiles in different areas and exposure conditions. 1234678-HpCDD and OCDD have observed to be the major PCDD congeners in the deposition samples in Pallas, in northern Finland [26].

WHO-PCDD/F-TEQs in moose muscle (Figure 2 a) (on average $1.3 \mathrm{pg} / \mathrm{g}$ fat) were equal with reindeer. The most dominating PCDD/F congeners in moose muscle tissue samples were OCDD, 23478-PeCDF, 1234678-HpCDF and $1234678-\mathrm{HpCDD}$ (Figure 3 a). OCDD concentration (28 pg/g fat) was noticeable high in male calf sample from the northern zone. That was a parallel result to the reindeer calf muscle and liver samples from the same sampling zone, and indicated high OCDD exposure in the northern part of Finnish Lapland. Also 1234678-HpCDD showed an elevated concentration in northern zone's moose male calf. A similar phenomenon was observed in reindeer calves from the northern zone.

Lower OCDD and 1234678-HpCDD concentrations in northern zone's adult reindeer and adult moose may indicate different contaminant levels in emissions and exposure from food, in addition to individual physiological 


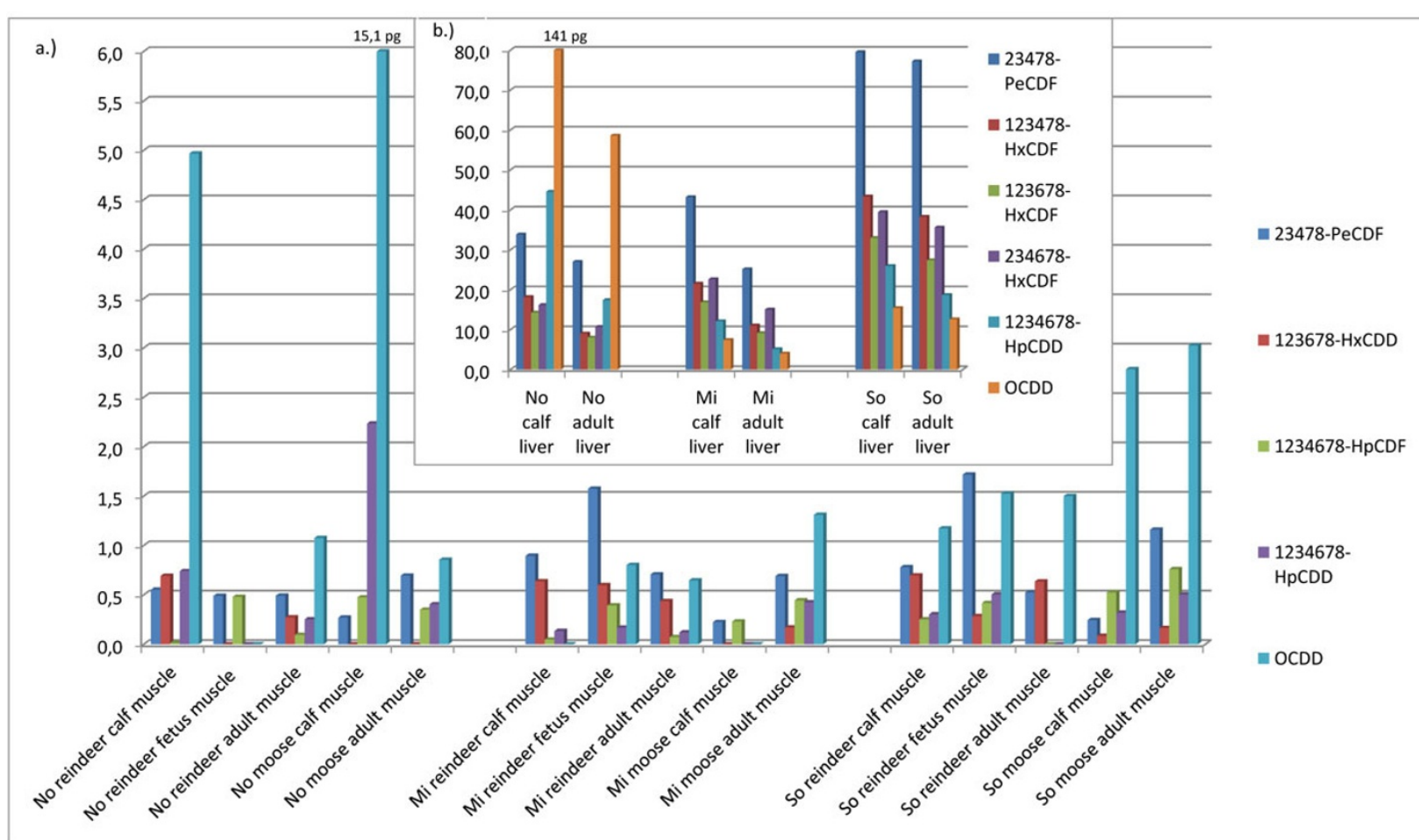

Figure 3. No=Northern zone, $\mathrm{Mi}=$ Middle zone, So=Southern zone

Figure 3 The most abundant PCDD/F congeners (pg/g fat) in a.) reindeer and moose muscle samples, and b.) in reindeer liver samples. $\mathrm{No}=$ Northern zone, Mi=Middle zone, So=Southern zone.

differences, but unlikely straight differences in metabolic activity and elimination potential. In middle and southern zones the exposure to especially OCDD may be lower and that is reflecting as the lower contamination both calves and adults. Concentration of 2378-TCDF was significantly $(P<0.05)$ higher in the adult moose than in moose calves. That was an opposite result than with reindeer.

Very similar concentrations of 23478-PeCDF, 123478HxCDF, 123678-HxCDF and 234678-HxCDF (TEF 0.1 in hexa-chlorinated congeners) in the livers of the southern zone's reindeer calves and adult reindeer could indicate equal amount of binding sites for dioxins in the liver. On the other hand, considering the concentrations of the same congeners in the northern and middle zones, it is seen that calves had general higher levels in their livers than adult reindeer. However, the total concentrations were lower in the northern and middle zones than in the southern zone, even though the differences were not statistically significant.

\section{$\mathrm{PCDD} / \mathrm{Fs}$ in reindeer milk samples}

$\mathrm{PCDD} /$ Fs in reindeer milk samples (Table 2) showed generally similar profile than in muscle and liver samples. WHO-PCDD/F-TEQ showed a decreasing trend from the summer sampling $(0.5 \mathrm{pg} / \mathrm{g}$ fat $)$ to autumn sampling
(0.4 pg/g fat) [20]. The most dominating congeners were 23478-PeCDF, 12378-PeCDD, 123478-HxCDF, 123678HxCDD, 1234678-HpCDD and OCDD. There was a decreasing trend in reindeer milk samples from summer to autumn in most of the congener concentrations. Statistically significant $(P<0.05)$ decrease were in the concentrations of 23478-PeCDF, 12378-PeCDD, 123478$\mathrm{HxCDF}$, 234678-HxCDF and 123678-HxCDD). However, 2378-TCDF, 1234678-HpCDD and OCDD showed significantly higher levels in the autumn than in the summer. In addition, OCDD, which showed the highest total contribution of PCDD/Fs, interestingly increased from zero in summer to on average $0.6 \mathrm{pg} / \mathrm{g}$ fat in autumn milk samples. Despite of increasing fat content of milk during the lactation period, the levels of some particular congeners were increased indicating no dilution effect.

\section{DL-PCBs in reindeer and moose tissue samples}

WHO-PCB-TEQs were higher in reindeer calf muscle (Figure 2 a) (on average $2.0 \mathrm{pg} / \mathrm{g}$ fat) than in adult reindeer (on average $1.2 \mathrm{pg} / \mathrm{g}$ fat). The highest level was seen in the middle sampling zone. The most dominating non-ortho-DL-PCB congener in reindeer muscle samples (Figure 4 a) was PCB-126, which highest concentration ( $39 \mathrm{pg} / \mathrm{g}$ fat) was detected in the middle zone's stillborn 
Table 2 PCDD/Fs (pg/g fat), non-ortho-DL-PCBs (pg/g fat), and mono-ortho-DL-PCBs (ng/g fat) in reindeer milk samples

\begin{tabular}{|c|c|c|}
\hline Congener & Summer milk & Autumn milk \\
\hline 2378-TCDF & 0.011 & 0.076 \\
\hline 2378-TCDD & 0.010 & $<\mathrm{LOQ}$ \\
\hline 12378-PeCDF & 0.033 & $<\mathrm{LOQ}$ \\
\hline 23478-PeCDF & 0.260 & 0.143 \\
\hline 12378-PeCDD & 0.143 & 0.016 \\
\hline $123478-\mathrm{H} \times C D F$ & 0.160 & 0.044 \\
\hline 123678-HxCDF & 0.063 & 0.024 \\
\hline 234678-HxCDF & 0.046 & $<\mathrm{LOQ}$ \\
\hline $123789-\mathrm{H} \times C D F$ & $<\mathrm{LOQ}$ & $<\mathrm{LOQ}$ \\
\hline 123478-HxCDD & 0.035 & $<\mathrm{LOQ}$ \\
\hline $123678-H \times C D D$ & 0.124 & 0.023 \\
\hline $123789-\mathrm{HxCDD}$ & $<L O Q$ & $<L O Q$ \\
\hline 1234678-HpCDF & $<\mathrm{LOQ}$ & $<\mathrm{LOQ}$ \\
\hline 1234789-HpCDF & $<\mathrm{LOQ}$ & $<\mathrm{LOQ}$ \\
\hline 1234678-HpCDD & 0.098 & 0.126 \\
\hline OCDF & $<\mathrm{LOQ}$ & $<\mathrm{LOQ}$ \\
\hline OCDD & $<\mathrm{LOQ}$ & 0.589 \\
\hline PCB-77 & $<L O Q$ & 0.970 \\
\hline PCB-81 & 0.062 & 0.364 \\
\hline PCB-126 & 5.070 & 2.653 \\
\hline PCB-169 & 0.798 & 0.511 \\
\hline PCB-105 & 0.176 & 0.122 \\
\hline PCB-114 & 0.012 & 0.008 \\
\hline PCB-118 & 0.404 & 0.390 \\
\hline PCB-123 & $<\mathrm{LOQ}$ & 0.005 \\
\hline PCB-156 & 0.091 & 0.060 \\
\hline PCB-157 & 0.015 & 0.008 \\
\hline PCB-167 & 0.025 & 0.022 \\
\hline PCB-189 & 0.009 & 0.009 \\
\hline
\end{tabular}

calf. That individual contained also quite high concentration of PCB-77 (18 pg/g fat), which was the other very frequent congener in the studied population. PCB77 was the only non-ortho congener being significantly $(P<0.05)$ higher in stillborn calves' muscle than in the other calves and adult reindeer. PCB-77 had also significantly $(P<0.05)$ higher levels in stillborn calves' muscle than in brown adipose tissue.

From non-ortho congeners, PCB-126 was the most dominating one in brown adipose (data not shown), followed by PCB-169. In addition, even if PCB-169 existed in many of the samples, it showed the highest level in the stillborn calf of the middle area (14.4 pg/g fat) (Figure 4 a). WHO-PCB-TEQ in stillborn calves' brown adipose (on average $5.5 \mathrm{pg} / \mathrm{g}$ fat) was higher than in muscle (on average $2.6 \mathrm{pg} / \mathrm{g}$ fat). Overall, there was a strong contribution of dioxin-like non-ortho-PCBs (PCB-77, -81, -126 and -169) to total TEQ in the reindeer muscle samples. Of the mono-ortho-PCBs, $\mathrm{PCB}-118$ was the most generally existing congener. In $38 \%$ of reindeer and moose tissue samples its concentration was above $1 \mathrm{ng} / \mathrm{g}$ fat (Table 3). The most congener containing monoortho-PCB profile was detected in middle area's stillborn reindeer calf that indicates effective transfer and accumulation of these contaminants to fetus.

PCB-126 was clearly the most dominating DL-PCB congener in reindeer liver samples (Figure $4 \mathrm{~b}$ ), followed by other non-ortho-PCB congeners PCB-77, -81 and -169 , which concentrations were, however, much lower. The highest concentration of PCB-126, $400 \mathrm{pg} / \mathrm{g}$ fat, was exceeded in the middle zone's female calf. TEF-value of PCB-126, 0.1, is the highest of DL-PCBs, thus influencing strongly to WHO-PCB-TEQ, which was higher in reindeer calf liver (on average $25 \mathrm{pg} / \mathrm{g}$ fat) than in adult reindeer liver (on average $12 \mathrm{pg} / \mathrm{g}$ fat) (Figure $2 \mathrm{~b}$ ). The overall non-ortho-DL-PCB profile in reindeer liver fitted well to reindeer muscle samples. DL-PCB concentrations were generally higher in calf liver samples than in adult reindeer liver. That may indicate the calf liver functions being in state of effective accumulation of toxicants and weak detoxification resulting high concentrations of non-metabolized compounds in calf livers. However, concentrations of PCB-77 were significantly $(P<0.05)$ higher in adult reindeer livers than in calves' livers.

WHO-PCB-TEQ in moose calf muscle (Figure 2 a) was slightly lower $(0.7 \mathrm{pg} / \mathrm{g}$ fat $)$ than in adult moose $(0.9 \mathrm{pg} / \mathrm{g}$ fat), that is opposite result than with reindeer. The most prominent non-ortho congener in moose muscle was PCB-77, followed by PCB-126 and PCB-81. Of monoortho- PCB congeners PCB-118 was the most detected one. There were no statistically significant differences between the DL-PCB concentrations in adult moose and moose calves. However, PCB-77 concentrations were significantly lower in female moose than in male moose in every zone, indicating excretion of compounds via lactation.

\section{DL-PCBs in reindeer milk samples}

The most prominent non-ortho-DL-PCB congener in reindeer milk (Table 2) was PCB-126; this concerns both summer and autumn samples, when the mean concentrations were 5 and $2.7 \mathrm{pg} / \mathrm{g}$ fat, respectively. A clear decrease in the concentration of PCB-126 is seen from summer to autumn. Similar significant, $(P<0.05)$ decreasing trend was seen also with non-ortho-PCB-169 (0.79 pg/g fat) in summer and $0.51 \mathrm{pg} / \mathrm{g}$ fat in autumn). However, PCB-81 increased significantly $(P<0.05)$ from $0.06 \mathrm{pg} / \mathrm{g}$ fat in summer to $0.36 \mathrm{pg} / \mathrm{g}$ fat in autumn, and PCB-77 from zero in summer to $0.97 \mathrm{pg} / \mathrm{g}$ fat in autumn. This was due to one exceptional high PCB-77 concentration $(6.79 \mathrm{pg} / \mathrm{g}$ fat) in autumn milk samples. PCB-118 remained steady $(0.4 \mathrm{ng} / \mathrm{g}$ fat). Concentrations of PCB-114, -156 and -157 were decreased and PCB-123 increased significantly $(P<0.05)$ 


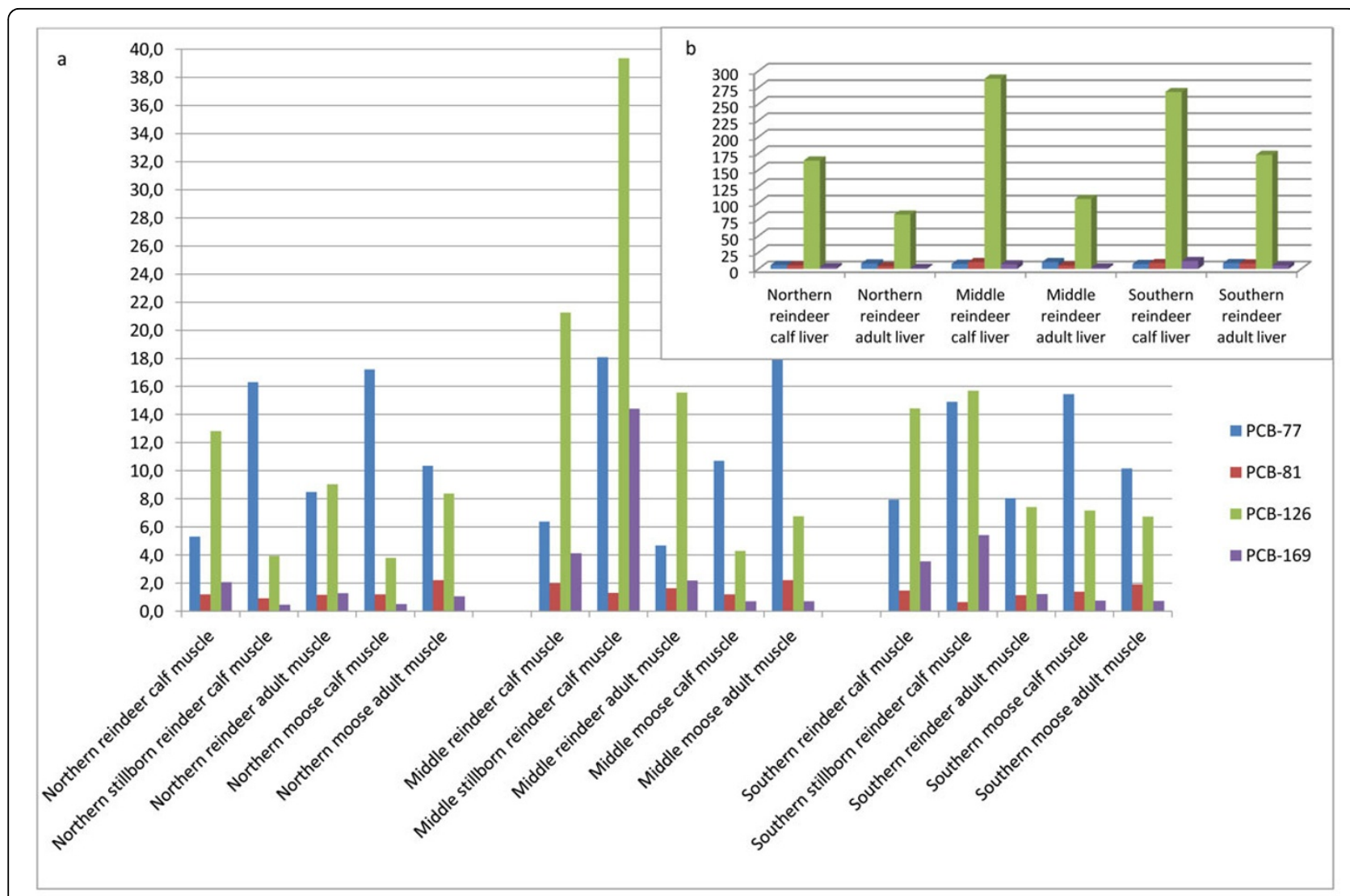

Figure 4.

Figure 4 Non-ortho-DL-PCBs (pg/g fat) in a.) reindeer and moose muscle samples, and b.) in reindeer liver samples.

Table 3 Mono-ortho-DL-PCBs (ng/g fat) in reindeer and moose tissue samples

\begin{tabular}{|c|c|c|c|c|c|c|c|c|}
\hline Sample & PCB-105 & PCB-114 & PCB-118 & PCB-123 & PCB-156 & PCB-157 & PCB-167 & PCB-189 \\
\hline Northern reindeer calf muscle & 0.35 & 0.03 & 1.01 & 0.01 & 0.13 & 0.03 & 0.03 & 0.01 \\
\hline Northern reindeer calf liver & 0.54 & 0.02 & 1.16 & 0.01 & 0.12 & 0.03 & 0.03 & 0.01 \\
\hline Northern stillborn reindeer calf muscle & 0.13 & 0.01 & 0.36 & $<\mathrm{LOQ}$ & $<\mathrm{LOQ}$ & 0.01 & $<\mathrm{LOQ}$ & $<\mathrm{LOQ}$ \\
\hline Northern reindeer adult muscle & 0.27 & 0.02 & 0.69 & 0.01 & 0.08 & 0.02 & 0.03 & 0.01 \\
\hline Northern reindeer adult liver & 0.29 & 0.01 & 0.57 & 0.01 & 0.05 & 0.01 & 0.02 & $<\mathrm{LOQ}$ \\
\hline Northern moose calf muscle & 0.13 & 0.01 & 0.42 & 0.02 & 0.03 & 0.01 & 0.02 & $<\mathrm{LOQ}$ \\
\hline Northern moose adult muscle & 0.27 & 0.02 & 0.86 & 0.03 & 0.09 & 0.02 & 0.04 & 0.01 \\
\hline Middle reindeer calf muscle & 0.65 & 0.05 & 1.72 & 0.02 & 0.28 & 0.07 & 0.06 & 0.02 \\
\hline Middle reindeer calf liver & 1.11 & 0.04 & 2.22 & 0.02 & 0.28 & 0.07 & 0.07 & 0.02 \\
\hline Middle stillborn reindeer calf muscle & 1.32 & 0.16 & 4.04 & 0.02 & 1.12 & 0.24 & 0.20 & 0.09 \\
\hline Middle reindeer adult muscle & 0.43 & 0.03 & 0.96 & 0.01 & 0.14 & 0.04 & 0.05 & 0.01 \\
\hline Middle reindeer adult liver & 0.67 & 0.02 & 1.03 & 0.01 & 0.12 & 0.04 & 0.04 & 0.01 \\
\hline Middle moose calf muscle & 0.16 & 0.01 & 0.57 & 0.02 & 0.07 & 0.01 & 0.03 & 0.01 \\
\hline Middle moose adult muscle & 0.25 & 0.02 & 0.79 & 0.04 & 0.07 & 0.01 & 0.04 & 0.01 \\
\hline Southern reindeer calf muscle & 0.44 & 0.04 & 1.04 & 0.01 & 0.25 & 0.06 & 0.05 & 0.03 \\
\hline Southern reindeer calf liver & 0.99 & 0.04 & 1.64 & 0.01 & 0.38 & 0.09 & 0.08 & 0.03 \\
\hline Southern stillborn reindeer calf muscle & 0.33 & 0.05 & 0.71 & 0.01 & 0.41 & 0.08 & 0.05 & 0.05 \\
\hline Southern reindeer adult muscle & 0.22 & 0.02 & 0.45 & 0.01 & 0.09 & 0.02 & 0.02 & 0.01 \\
\hline Southern reindeer adult liver & 0.55 & 0.02 & 0.93 & 0.01 & 0.16 & 0.04 & 0.04 & 0.01 \\
\hline Southern moose calf muscle & 0.32 & 0.02 & 0.94 & 0.04 & 0.10 & 0.02 & 0.04 & 0.01 \\
\hline Southern moose adult muscle & 0.26 & 0.02 & 0.76 & 0.04 & 0.07 & 0.01 & 0.03 & 0.01 \\
\hline
\end{tabular}


from summer to autumn, concentrations being nevertheless very low.

The congener profile of DL-PCBs in reindeer milk was again fitted well to reindeer muscle and liver samples. Especially the most toxic DL-PCB-126 was well represented. WHO-PCB-TEQ in summer milk samples, on average $0.6 \mathrm{pg} / \mathrm{g}$ fat, decreased to $0.4 \mathrm{pg} / \mathrm{g}$ fat in autumn [20] that indicates transfer of DL-PCBs out of the body of female reindeer via lactational route. However, even emphasizing the importance of lactational transfer of persistent organic compounds it is worth of noticing that the highest concentrations of PCB-126 and -169 were found from stillborn calf that had got its body burden only via the placenta.

The mean fat content in autumn milk samples (26\%) was significantly $(P<0.05)$ higher than in summer milk samples $(10 \%)$ that may has an influence to the lipid based concentrations detected. The fat content of reindeer milk normally varies from 11 to $30 \%$ during the lactation process [27].

\section{Conclusions}

WHO-PCDD/F-TEQs were generally higher in reindeer calf muscle than in adult reindeer. PCDD/Fs showed partly similar profiles in reindeer and moose muscle, reindeer liver and milk samples-indicating equal mode of bioaccumulation. Among the most abundant congeners were 23478-PeCDF, 123478-HxCDF, 123678-HxCDF, 234678HxCDF, 1234678-HpCDD and OCDD. However, stillborn calves' brown adipose was somewhat exception showing both accumulation and absence of congeners compared to muscle. In addition, more infrequent $\mathrm{PCDD} / \mathrm{F}$ congeners existed in moose muscle samples; OCDD being the most visible. OCDD also showed interesting appearance to the reindeer milk $\mathrm{PCDD} / \mathrm{F}$ set not until in the autumn. With DL-PCBs, a strong contribution of non-ortho-PCBs (PCB$77,-81,-126$ and -169$)$ to total TEQ was detected in all studied samples, although there were some differences in the frequent of particular congeners in the different species. Differences found in this study may indicate species-, individual- and tissue-specific accumulation of PCDD/Fs and DL-PCBs. In addition to metabolic potential, which concerns mainly liver, an extent and quality of exposure may explain the congener-specific accumulation.

\section{List of abbreviations used \\ HRGC/HRMS: High resolution gas chromatography/high resolution mass spectrometer; WHO-TEQ: Toxic equivalent defined by WHO; WHO-PCDD/F- TEQ: Toxic equivalent for 17 PCDD/Fs; WHO-PCB-TEQ: Toxic equivalent for 12 DL-PCBs; TEF-value: Toxic Equivalence Factor; LOQ: Limit of quantification.}

\section{Acknowledgements and funding}

The study planning, sampling and chemical analyses were financially supported by the Ministry of Agriculture and Forestry. Funding of the data analysis and writing was provided through the grants from the Finnish Cultural Foundation, Thule Institute and Oulun läänin Talousseuran maataloussäätiö. Technical assistance was performed by the staff of Finnish Food Safety Authority Evira, National Institute for Health and Welfare and Finnish Game and Fisheries Research Institute.

Matti Viluksela is warmly thanked for valuable comments and corrections to the manuscript.

\section{Author details}

${ }^{1}$ University of Oulu, Department of Biology, P.O. Box 3000, 90014 Oulu, Finland. ${ }^{2}$ Finnish Food Safety Authority Evira, Risk Assessment Research Unit, Mustialankatu 3,00790, Helsinki, Finland. ${ }^{3}$ National Institute for Health and Welfare, Department of Environmental Health, P.O. Box 95, 70701, Kuopio, Finland. ${ }^{4}$ Finnish Game and Fisheries Research Institute, Reindeer Research Station, Toivoniementie 246, 99100 Kaamanen, Finland. ${ }^{5}$ University of Helsinki, P. O. Box 33, 00014, Helsinki, Finland.

\section{Authors' contributions}

Study design: SL. Data collection: SL, MN. Analysis of samples: PR. Data analysis: AS, SL. Statistical analysis: AS. Manuscript writing: AS. Critical review and approval of the final manuscript: AS, AH, PR, HK, MN, SL.

\section{Competing interests}

The authors declare that they have no competing interests.

Published: 24 February 2012

\section{References}

1. UNEP: Final Act of the Conference of Plenipotentiaries on the Stockholm Convention On Persistent Organic Pollutants. Geneva, Switzerland; 2001.

2. AMAP: AMAP Assessment Persistent Organic Pollutants in the Arctic. Arctic Monitoring and Assessment Programme, Oslo; 2004.

3. AMAP: AMAP Assessment Arctic Pollution. Arctic Monitoring and Assessment Programme, Oslo; 2009.

4. de March BGE, de Wit CA, Muir DCG, Braune BM, Gregor DJ, Norstrom RJ: Persistent Organic Pollutants. AMAP Assessment Report: Arctic Pollution Issues Oslo; 1998.

5. WHO: PCBs, PCDDs and PCDFs: Prevention and Control of Accidental and Environmental Exposures. Environmental Health Series WHO Regional Office for Europe, Copenhagen, Denmark; 1987, No. 23.

6. Letcher RJ, Klasson-Wehler E, Bergman $\AA$ : Methyl sulfone and hydroxylated metabolites of polychlorinated biphenyls. In The Handbook of Environmental Chemistry. Volume 3. Springer-Verlag, Berlin, Heidelberg, Germany;J. Paasivirta 2000:315-360, Part K, New Types of Persistent Halogenated Compounds.

7. Jansson B, Jensen S, Olsson M, Renberg L, Sundström G, Vaz R: Identification by GC-MS of phenolic metabolites of PCB and p, $p^{\prime}-\mathrm{DDE}$ isolated from Baltic guillemot and seal. Ambio 1975, 4:87-92.

8. Stober J: Health effects of POPs. Proceedings of the Subregional Awareness Raising Workshop on Persistent Organic Pollutants (POPS): 11-14 May 1998; Kranjska Gora, Slovenia

9. Lilienthal H, Hack A, Roth-Harer A, Grande SW, Talsness CE: Effects of developmental exposure to 2, 2', 4, 4', 5- pentabromodiphenyl ether (PBDE-99) on sex steroids, sexual development, and sexually dimorphic behavior in rats. Environ Health Perspect 2006, 114:194-201.

10. Bustnes JO, Erikstad KE, Hanssen SA, Tveraa T, Folstad I, Skaare JU: Antiparasite treatment removes negative effects of environmental pollutants on reproduction in an Arctic seabird. Proc Biol Sci 2006, 273:3117-22.

11. Van Oostdam J, Donaldson SG, Feeley M, Arnold D, Ayotte P, Bondy G, Chan L, Dewaily E, Furgal CM, Kuhnlein H, Loring E, Muckle G, Myles E, Receveur O, Tracy B, Gill U, Kalhok S: Human health implications of environmental contaminants in Arctic Canada: a review. Sci Total Environ 2005, 351-352:165-246.

12. Bordajandi LR, Carletti A, Di Domenico A, Cravedi JP, Fürst $P$, Nebbia A, Schrenk D: EFSA's risk assessment on the presence of high levels of dioxins and dioxin-like PCBs in liver from sheep. Organohalogen Compd.

13. Krahn MM, Ylitalo GM, Burrows DG, Calambokidis J, Moore SE, Gosho M, et al: Organochlorine contaminant concentrations and lipid profiles in eastern North Pasific gray whales (Eschrichtius robustus). J Cetacean Res Manag 2001, 3:19-29.

14. Kelly BC, Gobas FAPC: An arctic terrestrial food chain bioaccumulation model for persistent organic pollutants. Environ Sci Technol 2003, 37:2966-74. 
15. Schröter-Kermani C, Rappolder M, Neugebauer F, Päpke O: PCDD, PCDF, and DL-PCB in terrestrial ecosystems: Are there correlations of levels or patterns in soil and roe deer liver? Organohalogen Compd.

16. Suutari $A$, Ruokojärvi $P$, Hallikainen $A$, Kiviranta $H$, Laaksonen $S$ :

Polychlorinated dibenzo-p-dioxins, dibenzofurans, and polychlorinated biphenyls in semi-domesticated reindeer (Rangifer tarandus tarandus) and wild moose (Alces alces) meat in Finland. Chemosphere 2009, 75:617-622.

17. Harden F, Mueller JF, Toms L-ML, Gaus C, Moore M, Paepke O, et al: Determination of the levels of dioxin in the Australian population by analysis of blood serum. Organohalogen Compd 2004, 66:2853-2858.

18. Kim B-H, Ikonomou MG, Lee S-J, Kim H-S, Chang Y-S: Concentrations of polybrominated diphenyl ethers, polychlorinated dibenzo-p-dioxins and dibenzofurans, and polychlorinated biphenyls in human blood samples from Korea. Sci Total Environ 2005, 336:45-56.

19. Kiviranta $H$, Hallikainen $A$, Ruokojärvi $P$, Rantakokko $P$, Vartiainen T: PCDD/F, PCB and PBDE levels in Finnish foodstuffs in 2003-2005. Organohalogen Compd 2006, 68:1898-1901.

20. Ruokojärvi $P$, Laaksonen $S$, Suutari A, Kiviranta $H$, Vartiainen T: Levels of $\mathrm{PCDD} / \mathrm{Fs}$ and $\mathrm{PCBs}$ in reindeer-first results of the Finnish study on POPs in reindeer food chain. Organohalogen Compd 2007, 69:2319-22.

21. Jenssen BM: Endocrine disrupting chemicals and climate change: a worst case combination for Arctic marine mammals and seabirds? Environ Health Perspect 2006, 114:76-80.

22. Wiborg ML, Knutsen HK, Andersson Ö, Büchert A, Cederberg T, Darnerud PO, Hallikainen A, Kiviranta H, Ólafsdóttir K, Peters K: EU maximum levels for dioxins and dioxin-like PCBs - Impact on exposure and food supply in the Nordic countries, Nordic Council of Ministers. 2008.

23. Van den Berg M, Birnbaum L, Denison M, De Vito M, Farland W, Feeley $M$, Fiedler H, Hakansson H, Hanberg A, Haws L, Rose M, Safe S, Schrenk D, Tohyama C, Tritscher A, Tuomisto J, Tysklind M, Walker N, Peterson RE: Human and mammalian toxic equivalency factors for dioxins and dioxinlike compounds: The WHO 2005 re-evaluation. Organohalogen Compd 2006, 68:834-835.

24. European Commission regulation (EC) No. 1881/2006 of 19 December 2006 setting maximum levels for certain contaminants in foodstuffs. Off. J. L 2006, 364:3-24.

25. Casabona H, Lindström G, van Bavel B, Manzoor E, Ahlborg UG, Rappe C, Håkansson H: Distribution and elimination of individual polychlorinated dibenzofurans (PCDFs) in the liver and adipose tissue of rat, hamster, guinea pig and mouse. Organohalogen Compd 1998, 37:377-380.

26. Kiviranta $\mathrm{H}$ : Exposure and Human PCDD/F and PCB Body Burden in Finland. PhD thesis National Public Health Institute, Department of Environmental Health; 2005.

27. Holand $\varnothing$, Gjøstein G, Nieminen M: Reindeer milk. In Handbook of Milk of Non-bovine Mammals. Ames, lowa: Blackwell Publishing Professional;Park YW \& Haenlein GFW 2006:355-370.

doi:10.1186/1751-0147-54-S1-S11

Cite this article as: Suutari et al:: Persistent organic pollutants in Finnish reindeer (Rangifer tarandus tarandus L.) and moose (Alces alces). Acto Veterinaria Scandinavica 2012 54(Suppl 1):S11.

\section{Submit your next manuscript to BioMed Central and take full advantage of:}

- Convenient online submission

- Thorough peer review

- No space constraints or color figure charges

- Immediate publication on acceptance

- Inclusion in PubMed, CAS, Scopus and Google Scholar

- Research which is freely available for redistribution

Submit your manuscript at www.biomedcentral.com/submit
Ciomed Central 